\title{
Growth and Physiological Responses of Adenophora triphylla (Thunb.) A.DC. Plug Seedlings to Day and Night Temperature Regimes
}

\author{
Ya Liu ${ }^{1}{ }^{(\mathbb{D}}$, Xiuxia Ren $^{1}{ }^{(\mathbb{C}}$, Hai Kyoung Jeong ${ }^{1}$, Hao Wei ${ }^{1}$ and Byoung Ryong Jeong ${ }^{1,2,3, *}$ \\ 1 Division of Applied Life Science (BK21 Plus Program), Graduate School, Gyeongsang National University, \\ Jinju 52828, Korea; liuya113@mails.ucas.ac.cn (Y.L.); xiuxia0823@163.com (X.R.); hksmile@naver.com (H.K.J.); \\ oahiew@gmail.com (H.W.) \\ 2 Institute of Agriculture and Life Science, Gyeongsang National University, Jinju 52828, Korea \\ 3 Research Institute of Life Sciences, Gyeongsang National University, Jinju 52828, Korea \\ * Correspondence: brjeong@gnu.ac.kr; Tel.: +82-55-772-1913
}

Received: 11 July 2018; Accepted: 28 August 2018; Published: 1 September 2018

\begin{abstract}
Adenophora triphylla (Thunb.) A.DC., three-leaf lady bell, is an important medicinal plant used against cancers and obesity. It has been well-established that the temperature regime affects plant growth and development in many ways. However, there is no study available correlating the growth of $A$. triphylla seedlings with different day and night temperature regimes. In order to find an optimal temperature regime, growth and physiology were investigated in A. triphylla plug seedlings grown in environment-controlled chambers at different day and night temperatures: $20 / 20^{\circ} \mathrm{C}$ (day/night) (TA), $25 / 15^{\circ} \mathrm{C}(\mathrm{TB})$, and $20 / 15^{\circ} \mathrm{C}$ (TC). The seedlings in plug trays were grown under a light intensity of $150 \mu \mathrm{mol} \cdot \mathrm{m}^{-2} \cdot \mathrm{s}^{-1} \mathrm{PPFD}$ (photosynthetic photon flux density) provided by white LEDs, a $70 \%$ relative humidity, and a $16 \mathrm{~h}$ (day) $/ 8 \mathrm{~h}$ (night) photoperiod for six weeks. The results showed that the stem diameter, number of roots, and biomass were significantly larger for seedlings in TB than those in TA or TC. Moreover, the contents of total flavonoid, total phenol, and soluble sugar in seedlings grown in TB were markedly higher than those in seedlings in the other two treatments. Soluble protein content was the lowest in seedlings in TC, while starch content was the lowest in seedlings grown in TA. Furthermore, seedlings grown in TB showed significantly lower activities of antioxidant enzymes such as superoxide dismutase, catalase, ascorbate peroxidase, and guaiacol peroxidase. Native PAGE (polyacrylamide gel electrophoresis) analysis further proved low activities of antioxidant isozymes in TB treatment. Meanwhile, the lowest content of hydrogen peroxide was observed in seedlings grown in TB. In conclusion, the results suggested that the $25 / 15^{\circ} \mathrm{C}$ (day/night) temperature regime is the most suitable for the growth and physiological development of $A$. triphylla seedlings.
\end{abstract}

Keywords: Adenophora triphylla (Thunb.) A.DC.; antioxidant enzymes; isozyme; native-PAGE; stress; temperature; secondary metabolites

\section{Introduction}

Adenophora triphylla (Thunb.) A.DC. (Campanulaceae), also known as the three-leaf lady bell or the Japanese lady bell, is a species mainly found in Korea, China (from northeast to south), Japan, and Russia (Far East and Eastern Siberia). In addition to having ornamental values, A. triphylla is a very important medicinal plant in oriental medicine. It is also known as "Sha-shen" in Chinese and "Jan-dae" in Korean. The Chinese crude drug "shajin", extracted from the roots of A. triphylla, is an effective expectorant for the treatment of whooping cough and chronic bronchitis, and its pharmaceutical 
name is Radix Adenophorae [1,2]. Historically, A. triphylla was used as food to prevent obesity in Korea [2,3]. In recent years, many more medicinal effects of $A$. triphylla have been reported, such as anti-cancerous, anti-diabetic, and antioxidant [4]. Although the contents slightly fluctuate depending on the growth condition and genotype of individual variety, it has been proved that $A$. triphylla holds various phytochemicals, such as $\beta$-sitosterol, lupenone, daucosterol, triphyllol, and adenophoric acid methyl ester [5-7]. Previous research focused on separation, extract, and characterization of those phytochemicals and on the disease-fighting medicinal mechanisms of $A$. triphylla [3,8-10]. However, there are no studies available reporting on the growth and physiology of plug seedlings of this species.

Seedling growth is influenced by a series of ecological factors, including biotic and abiotic factors [11]. Temperature is a main abiotic factor influencing the growth and physiology of seedlings [11-15]. For example, positive difference between day and night temperatures (DIF) and high average daily temperature (ADT) enhance plant growth and development [16-19]. Recently, it was proved that low night temperature has a positive effect on growth and metabolism by enhancing biosynthesis capacity and reducing respiration [20-22]. However, stress of temperature, either high or low, induces overproduction of reactive oxygen species (ROS), causing damage to nucleic acids, proteins, and lipids, and as a consequence, severely limits the growth of plants [14,23]. As plants evolved, they have developed a number of sophisticated strategies to combat temperature stresses, such as detoxifying ROS, adjusting the osmotic potential, maintaining an ionic homeostasis, etc. [24-26]. In order to minimize stress-induced damages, the expression of antioxidant enzymes, such as superoxide dismutase (SOD), catalase (CAT), ascorbate peroxidase (APX), and guaiacol peroxidase (GPX), was promptly induced [27]. For example, high temperature (usually more than $30^{\circ} \mathrm{C}$ ) induces a high expression of antioxidant enzymes to scavenging ROS [23,28,29]. Low temperature (less than $15{ }^{\circ} \mathrm{C}$ ) has a similar effect on those enzymes [23,30,31]. However, more studies should focus on the response of antioxidant enzymes under a moderate temperature range between chilling and heat. Furthermore, for each kind of antioxidant enzyme, isozymes catalyzing the same chemical reaction with different structures are activated differentially in detoxifying ROS process under various conditions [32-34]. Clearly, an in-depth study of the expression and activity of the various antioxidant isozymes under temperature regimes is necessary to figure out antioxidant system and self-defending mechanism in plant. Native-polyacrylamide gel electrophoresis (native-PAGE) is an effective technology used to separate isozymes while retaining aspects of their activity $[35,36]$. And the band intensity was closely dependent on the activities of isozymes. Hence, this method was always used to assess the activity of isozymes together with quantitative analysis of antioxidant enzyme activities $[32,37,38]$.

As valuable compounds, total phenols and flavonoids change with day and night temperature. Previous studies showed that slightly elevated temperature could enhance secondary metabolites such as saponins, phenolic compounds, and flavonoids $[39,40]$. Adversely, some research argued that the total polyphenol and anthocyanin (one kind of flavonoids) were the higher in low temperature rather than high temperature $[29,41]$. Thus further studies are still necessary. Importantly, plants employ secondary metabolites, such as phenols and flavonoids, to scavenge those free radicals and protect cells from ROS damage [42,43]. Therefore, assessing the levels of these metabolites is of importance in the determination of antioxidant capacity of plants. Additionally, since those phenols and flavonoids contain great medicinal and commercial value, the content estimation of those compounds in special species such as A. triphylla carries more significance for future studies.

In the present study, we hypothesize that temperature regimes with larger DIF and high ADT could improve the quality of $A$. triphylla seedlings by promoting the growth and development, accumulating more primary and secondary metabolites, and maintaining a physiological homeostasis. Our objectives are to verify whether $25 / 15{ }^{\circ} \mathrm{C}$ could be an optimum temperature regime or not and to evaluate the growth and physiological responses of $A$. triphylla seedlings to various day and night temperature regimes. To test our hypothesis, we investigated the growth, development, and metabolism characteristics of $A$. triphylla plug seedlings at different day/night temperatures: $20 / 20{ }^{\circ} \mathrm{C}$ 
(day/night) (TA), $25 / 15^{\circ} \mathrm{C}$ (TB), and $20 / 15^{\circ} \mathrm{C}$ (TC). We further estimated the hydrogen peroxide $\left(\mathrm{H}_{2} \mathrm{O}_{2}\right)$ content, the activities of antioxidant enzymes including SOD, CAT, APX, and GPX, and the expression of antioxidant isozymes. These data could provide a theoretical and practical basis for promoting growth and improving the medicinal value of $A$. triphylla by controlling the temperature regime, as well as be useful information for the management of other medicinal plants.

\section{Materials and Methods}

\subsection{Plant Materials and Treatments}

Adenophora triphylla seeds were sown in 200-cell plug trays in the greenhouse. After germination, uniform seedlings with two cotyledons were selected, transplanted into 72-cell trays, and then transferred into three growth chambers equally under different temperature regimes (Table 1): $20 / 20^{\circ} \mathrm{C}$ (day/night) (TA), $25 / 15^{\circ} \mathrm{C}(\mathrm{TB})$, and $20 / 15^{\circ} \mathrm{C}$ (TC). All seedlings were cultured under a light intensity of $150 \mu \mathrm{mol} \cdot \mathrm{m}^{-2} \cdot \mathrm{s}^{-1}$ PPFD (photosynthetic photon flux density) provided by white LEDs, a $70 \%$ relative humidity, a $16 \mathrm{~h}$ (day) $/ 8 \mathrm{~h}$ (night) photoperiod, and a $390 \mu \mathrm{mol} \cdot \mathrm{mol}^{-1}$ carbon dioxide for six weeks. Sub-irrigation was used to provide water for seedling growth every 2 or 3 days. Growth parameters, such as the length and biomass of shoot and root, the number of leaves and roots, and stem diameter, were measured at $0,1,2,4$, and 6 weeks. After a 6-week culture, all leaves of seedlings were harvested in the morning (about 10 a.m.), immediately frozen in liquid nitrogen, and then stored in a $-80^{\circ} \mathrm{C}$ freezer until further processing.

Table 1. Different temperature regimes: $20 / 20^{\circ} \mathrm{C}$ (day/night) (TA), $25 / 15^{\circ} \mathrm{C}$ (TB), and $20 / 15^{\circ} \mathrm{C}$ (TC).

\begin{tabular}{ccccc}
\hline Treatment & DT $^{\mathbf{1}}$ & NT $^{\mathbf{2}}$ & ADT $^{\mathbf{3}}$ & DIF $^{\mathbf{4}}$ \\
\hline TA & 20 & 20 & 20.0 & 0 \\
TB & 25 & 15 & 21.7 & 10 \\
TC & 20 & 15 & 18.3 & 5 \\
\hline
\end{tabular}

${ }^{1}$ Day temperature, ${ }^{2}$ night temperature, ${ }^{3}$ average daily temperature, ${ }^{4}$ the difference between day and night temperatures.

\subsection{Measurement of Soluble Protein, Soluble Sugar, and Starch}

Soluble protein in leaves was measured by the Bradford protein assay [44]. In brief, samples $(0.15 \mathrm{~g})$ were homogenized using liquid nitrogen and then extracted with a sodium phosphate buffer $(1.5 \mathrm{~mL})$ for $10 \mathrm{~min}$. The extract was centrifuged at $12,000 \mathrm{rpm}$ for $20 \mathrm{~min}$ at $4{ }^{\circ} \mathrm{C}$ and the supernatant was used for assays. The supernatant $(50 \mu \mathrm{L})$ was mixed with the Braford reagent $(1450 \mu \mathrm{L})$. After $10 \mathrm{~min}$ of incubation, the absorbance of the mixed solution was recorded at $595 \mathrm{~nm}$ by a UV spectrophotometer (Libra S22, Biochrom Ltd., Cambridge, UK). The contents of soluble protein were estimated using the bovine serum albumin (BSA) as the standard.

Soluble sugar and starch in leaves were measured via the anthrone colorimetric method. Briefly, samples $(0.3 \mathrm{~g})$ were homogenized and then extracted with distilled water $(50 \mathrm{~mL})$ for $30 \mathrm{~min}$ at $100{ }^{\circ} \mathrm{C}$. After centrifugation at $3000 \mathrm{rpm}$ for $15 \mathrm{~min}$, the supernatant was collected and used for measurement of soluble sugar. Insoluble substance was extracted again in distilled water $(20 \mathrm{~mL})$ and perchloric acid $(2 \mathrm{~mL}, 52 \%)$ for measurement of starch. The supernatant $(0.1 \mathrm{~mL})$ of soluble sugar and starch was mixed with distilled water $(1.9 \mathrm{~mL})$, anthrone $(0.5 \mathrm{~mL})$, and concentrated sulfuric acid $(5 \mathrm{~mL})$. After $10 \mathrm{~min}$ of incubation, the absorbance of the mixed solution was recorded at $630 \mathrm{~nm}$ and $485 \mathrm{~nm}$ by a UV-spectrophotometer (Libra S22, Biochrom Ltd., Cambridge, UK), respectively. The calibration curves were constructed with standard solutions of sucrose and starch, respectively [45].

\subsection{Determination of Total Phenol and Flavonoid}

For determining contents of total phenol and flavonoid, $3 \mathrm{~g}$ of the samples were homogenized using liquid nitrogen and extracted with $6 \mathrm{~mL}$ of methanol (80\%). The extracts were incubated for $12 \mathrm{~h}$ 
in a shaker (KSI-200FL, Koencon, Hanam, Korea) at $110 \mathrm{rpm}$, and then centrifuged at 12,000 rpm for $15 \mathrm{~min}$. Supernatant was used for assays.

Total phenol content was determined by the Folin-Ciocalteu method [46]. To briefly explain the method, $0.1 \mathrm{~mL}$ of the supernatant, diluted up to $1.0 \mathrm{~mL}$ with double distilled water, was mixed with $0.5 \mathrm{~mL}$ of the Folin-Ciocalteu reagent (1:1 with water) and $1 \mathrm{~mL}$ of sodium carbonate solution (7.5\%). After a 40-min incubation in the dark, the absorbance was recorded at $725 \mathrm{~nm}$ by a UV spectrophotometer (Libra S22, Biochrom Ltd., Cambridge, UK) and the total phenol content was calculated from the calibration curve of standard gallic acid. Total flavonoid content was measured according to the aluminum chloride colorimetric method [42]. The supernatant $(0.1 \mathrm{~mL})$ was mixed with $0.9 \mathrm{~mL}$ of methanol $(80 \%)$ and $1 \mathrm{~mL}$ of aluminum chloride $(2 \%)$. After a 30 -min incubation, the absorbance of the mixed solution was measured at $415 \mathrm{~nm}$ by a UV spectrophotometer (Libra S22, Biochrom Ltd., Cambridge, UK) and the total flavonoid content was calculated based on the standard quercetin calibration curve.

\subsection{Estimation of $\mathrm{H}_{2} \mathrm{O}_{2}$ Content and Antioxidant Enzymes Activities}

Content of $\mathrm{H}_{2} \mathrm{O}_{2}$ was measured by the method of Manivannan et al. [46]. In detail, samples $(0.15 \mathrm{~g})$ were homogenized with $1.5 \mathrm{~mL}$ of TCA $(0.1 \%)$, followed by being centrifuged for $15 \mathrm{~min}$ at $12,000 \mathrm{rpm}$. The supernatant $(0.5 \mathrm{~mL})$, sodium phosphate buffer $(50 \mathrm{mM}, 0.5 \mathrm{~mL})$, and potassium iodide $(1 \mathrm{M}, 0.5 \mathrm{~mL})$ were mixed and then incubated for $30 \mathrm{~min}$ in the dark. The absorbance of mixture at $395 \mathrm{~nm}$ was recorded by a UV spectrophotometer (Libra S22, Biochrom Ltd., Cambridge, UK) and the $\mathrm{H}_{2} \mathrm{O}_{2}$ content was calculated according to the standard curve of $\mathrm{H}_{2} \mathrm{O}_{2}$.

To estimate the activities of antioxidant enzymes, samples $(0.1 \mathrm{~g})$ were ground and homogenized in a $50 \mathrm{mM}$ sodium phosphate buffer ( $\mathrm{pH} 7.0)$ including EDTA $(1 \mathrm{mM})$, triton $X(0.05 \%)$, and polyvinylpyrolidone (PVP, $1 \mathrm{mM}$ ). The extracts were centrifuged at $13,000 \mathrm{rpm}$ for $20 \mathrm{~min}$ at $4{ }^{\circ} \mathrm{C}$ and the supernatant was used in assaying the antioxidant enzymes activities. Activities of superoxide dismutase (SOD), guaiacol peroxidase (GPX), ascorbate peroxidase (APX), and catalase (CAT) were measured by a UV spectrophotometer (Libra S22, Biochrom Ltd., Cambridge, UK) based on the protocols of Manivannan et al. [47].

\subsection{Native PAGE Profiling of Antioxidant Enzymes and Quantification of Activity}

For profiling of antioxidant enzymes such as SOD, GPX, APX, and CAT, the native-polyacrylamide gel electrophoresis (native-PAGE) was performed based on previous methods [48,49]. Briefly, the electrophoresis was carried out using $12 \%$ separating and $4 \%$ stacking acrylamide gels and tris-glycine ( $\mathrm{pH}$ 8.3) running buffer at $4{ }^{\circ} \mathrm{C}$ for $4 \mathrm{~h}$ with a constant voltage ( 80 volts), after $30 \mu \mathrm{g}$ of extracted proteins were loaded on the top of the stacking gels. For the staining, the protocols described by researchers in References $[49,50]$ were followed. All gel staining procedures were accomplished at room temperature with a shaker (KSI-200FL, Koencon, Hanam, Korea) at $30 \mathrm{rpm}$ until the bands were visible and distinct. After staining, gels were washed with distilled water and then photographed by camera (EOS 100D, Canon, Tokyo, Japan) immediately.

To quantify the relative activities of isozymes of those enzymes among treatments, photos of gels were converted into black-and-white mode and the band intensities of isozymes were measured by Image 1.48 [51]. Then the relative activities of isozymes were calculated and presented as percentage (\%) of the control (TA) [38,49].

\subsection{Statistical Analysis}

All treatments were set up in a completely randomized design, and all assays were performed at least three individual biological repeats. Data, presented as the mean \pm standard error of the mean, were subjected to one-way analysis of variance (one-way ANOVA) to assess the differences among seedlings under different treatments, followed by the Duncan multiple range test at a $5 \%$ probability 
level, using the SPSS (Statistical Package for the Social Sciences, version 21). All figures were plotted using OriginPro software (version 9.0).

\section{Results and Discussion}

\subsection{Seedling Growth Characteristics under Different Temperature Regimes}

Temperature is one of the environmental factors that determine growth characteristics and shape morphological features in plants [14,52]. We found that different temperature regimes significantly influenced the growth and morphology of $A$. triphylla seedlings (Figure 1). The greatest number of roots (37.0 \pm 5.3 ) was observed for seedlings in TB on week 6 (Figure 1A). Similarly, the largest stem diameter and total dry weight were $1.92 \pm 0.10 \mathrm{~mm}$ and $0.056 \pm 0.007 \mathrm{~g}$, respectively for seedlings in TB (Figure 1B,C), both significantly higher than those for seedlings in TA and TC in the sixth week. Larger DIF and high ADT in TB (Table 1) promoted seedling growth, resulting in larger growth parameters than for seedlings in other treatments. Similar results have been reported in many other studies. Si and Heins [17] showed that the DIF had a significant effect on growth parameters such as the stem diameter, internode length, and leaf area in sweet pepper seedlings. Yang et al. [18] suggested that positive DIFs have higher positive influence than negative DIFs do, and a $6{ }^{\circ} \mathrm{C}$ DIF is best for greenhouse tomato growth. Li et al. [16] found that an $8^{\circ} \mathrm{C} \mathrm{DIF} \mathrm{could} \mathrm{significantly} \mathrm{improve} \mathrm{the} \mathrm{growth}$ and development in tomato LA1781, when compared with a DIF of $6{ }^{\circ} \mathrm{C}$. Ribeiro et al. [19] reported that Ricinus communis L. seedlings grown at $25^{\circ} \mathrm{C}$ and $35^{\circ} \mathrm{C}$ showed greater biomass than seedlings grown at $20^{\circ} \mathrm{C}$.
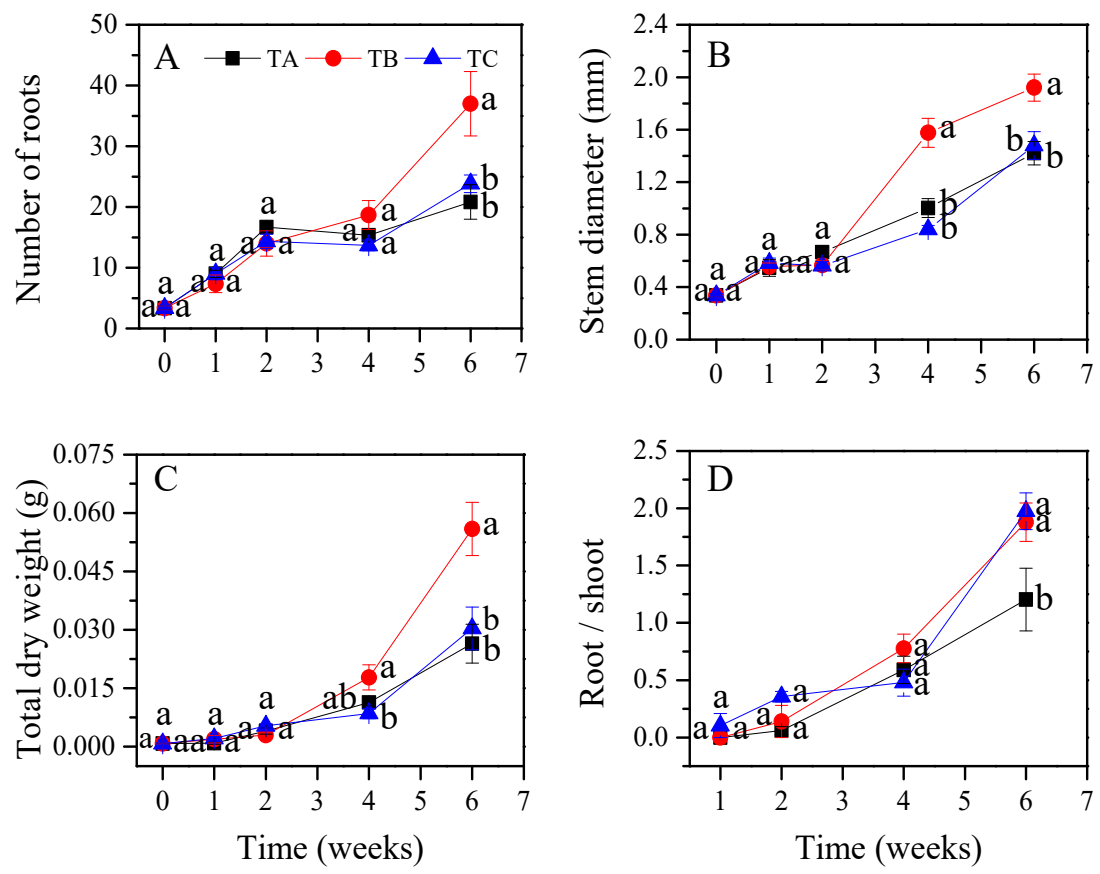

Figure 1. Number of roots (A), stem diameter (B), total dry weight (C), and root shoot ratio (D) of Adenophora triphylla (Thunb.) A.DC. seedlings grown under different temperature regimes. $\mathrm{TA}, 20 / 20^{\circ} \mathrm{C}$ (day/night); $\mathrm{TB}, 25 / 15^{\circ} \mathrm{C} ; \mathrm{TC}, 20 / 15^{\circ} \mathrm{C}$. Data is presented as the mean \pm standard error $(n=3)$. The different letters $(\mathrm{a}, \mathrm{b}$, and $\mathrm{c})$ indicate significant differences $(p<0.05)$ among treatments.

After the fourth week, the number of roots, stem diameter, and total biomass for seedlings in TB treatment were greater than those for seedlings in TA or TC treatment. There were no observable differences in the first four weeks (Figure 1). According to logistic growth curves, seedlings were in the lag phase of growth in the first four weeks, and grew slowly and steadily. Next, seedlings in different treatments went into the exponential phase and started displaying differences. Other research 
showed similar characteristics of seedling growth. For example, Arena and Radice [53] reported that shoot elongation in Berberis buxifolia Lam. presented a sigmoid curve. Cookson et al. [54] reported that the elongation of leaves, tendrils, and internodes in grapevine was fitted with sigmoid curves. Lin et al. [55] also reported that the initial stage of the fruit growth resembled a sigmoid curve.

Meanwhile, the lowest root-shoot ratio observed for seedlings in TA (Figure 1D) suggested that positive DIF in TB and TC accelerate the photosynthetic product partitioning from shoots (source) to roots (sink). Si and Heins [17] reported that the root-shoot ratio decreases with increases in DT (day temperature) and DIF. Other studies have shown that positive DIFs increase leaf photosynthesis, root biomass accumulation, and root-shoot ratio, as well as enhance root activity and nutrient uptake, and as a consequence, tomato growth is promoted [18]. Moreover, low NT (night temperature) inhibits the respiration which consume energy and reduce accumulation of carbohydrates while high NT provides a contrary effect [56,57]. Lesjak et al. [58] found an increase in NT $\left(4{ }^{\circ} \mathrm{C}\right)$ contributes to a decrease in biomass of stem and branch and grain yield in Chilean Quinoa. However, no significant differences were found in growth parameters, including shoot and root length, number of leaves, and water content (Table S1), among those three treatments. Any significant differences among plants exposed to those parameters may need more time to develop. Our results strongly suggest that seedlings grown in TB treatment are stronger and more compact, implying that TB is the most suitable temperature regime for the growth of $A$. triphylla seedlings.

\subsection{Contents of Soluble Sugar, Starch, and Soluble Protein in Seedling Grown under Various Temperature Conditions}

As direct or indirect products of photosynthesis, primary metabolites, such as soluble sugar, starch, and soluble protein, were affected by the temperature regime because temperature influences photosynthesis. In our study, the largest content of soluble sugar was observed for seedlings leaves in TB $\left(120.4 \pm 6.0 \mathrm{mg} \cdot \mathrm{g}^{-1}\right)$, followed by TC $\left(100.7 \pm 3.4 \mathrm{mg} \cdot \mathrm{g}^{-1}\right)$ and TA $\left(86.1 \pm 3.7 \mathrm{mg} \cdot \mathrm{g}^{-1}\right)$ (Table 2). Elevated DIF and DT within a certain range promote activities of photosynthesis-related enzymes and increase the net photosynthetic rate [59]. Therefore, seedlings grown under TB synthesize more sugar compared with those under TA and TC. Meanwhile, a low NT suppresses the respiration of seedlings by decreasing activities of respiration-related enzymes, resulting in decreased consumption of organic matters, such as soluble sugar [60,61]. Additionally, as an osmolyte, soluble sugar maintains cell turgor and protects proteins and cell membranes from stress damage [62,63]. As a result, a high soluble sugar content promotes the growth of seedlings [64,65]. Therefore, a high level of soluble sugar for in seedlings in TB partly explained why seedlings grown in TB are stronger and more compact when compared to those grown in TA and TC (Figure 1).

Table 2. Contents of soluble sugar, starch, and soluble protein in leaves of A. triphylla (Thunb.) A.DC. seedlings under different temperature regimes (TA, $20 / 20{ }^{\circ} \mathrm{C}$ (day/night); $\mathrm{TB}, 25 / 15^{\circ} \mathrm{C} ; \mathrm{TC}, 20 / 15{ }^{\circ} \mathrm{C}$ ) after six weeks of cultivation.

\begin{tabular}{cccc}
\hline \multirow{2}{*}{ Treatment } & \multicolumn{3}{c}{${\text { Content }\left(\mathbf{m g} \cdot \mathbf{g}^{-\mathbf{1}}\right)}$} \\
\cline { 2 - 4 } & Soluble Sugar & Starch & Soluble Protein \\
\hline TA & $86.1 \pm 3.7 \mathrm{~b}$ & $69.9 \pm 3.8 \mathrm{~b}$ & $6.9 \pm 0.3 \mathrm{a}$ \\
TB & $120.4 \pm 13.7 \mathrm{a}$ & $83.6 \pm 2.2 \mathrm{ab}$ & $7.0 \pm 0.2 \mathrm{a}$ \\
TC & $100.7 \pm 3.4 \mathrm{ab}$ & $92.6 \pm 4.0 \mathrm{a}$ & $5.2 \pm 0.3 \mathrm{~b}$ \\
\hline
\end{tabular}

Data is shown as the mean \pm standard error $(n=3)$. Different letters in the same column indicate significant differences in measured quantities $(p<0.05)$.

Similar to soluble sugar, soluble protein content for plants grown under TB showed the highest value $\left(7.0 \pm 0.2 \mathrm{mg} \cdot \mathrm{g}^{-1}\right)$ compared to those under TA $\left(6.9 \pm 0.3 \mathrm{mg} \cdot \mathrm{g}^{-1}\right)$ and TC $\left(5.2 \pm 0.03 \mathrm{mg} \cdot \mathrm{g}^{-1}\right)$ (Table 2). A high level of soluble protein increases the tolerance to environmental stresses such as low temperature, high temperature, and drought [66-68]. However, the highest content of starch was found in TC, followed by TB and TA (Table 2). As a polymeric carbohydrate, starch is an important 
energy storage. Compared with seedlings in TA, a higher starch content for seedlings in TC implied that the decrease in night temperature promoted the accumulation of starch. Similarly, the starch content for seedlings in TB was higher than for those in TA, although the difference between them was not significant. Starch accumulated in the source leaf in the daytime and decreased in the following night-time due to respiration and translocation. Besides, low night temperatures slowed down respiration and decreased energy consumption [69]. Thereby, the accumulation of starch was promoted in seedlings grown under lower NT without regard to the differences of photosynthesis. This result is consistent with previous studies in tomato [69] and cotton [70].

\subsection{Total Phenol and Flavonoid Accumulation under Various Temperature Conditions}

The temperature regime not only has influenced primary metabolites such as soluble sugar, starch, and soluble protein, but also has effects on secondary metabolites. In our study, contents of total phenol and flavonoid were deeply affected by different temperature regimes (Figure 2). The content of total phenol for seedlings in TB was $12.5 \pm 0.0 \mathrm{mg} \cdot \mathrm{g}^{-1}$, higher than that those for seedlings in TA $\left(11.3 \pm 3.1 \mathrm{mg} \cdot \mathrm{g}^{-1}\right)$ and TC $\left(10.5 \pm 0.1 \mathrm{mg} \cdot \mathrm{g}^{-1}\right)$. This tendency is coincident with ADT (Table 1) implying slightly elevated day temperature have a positive effect on phenol accumulation [39,40]. However, low night temperature in TC showed a negative impact when compared with TA, suggesting elevation in night temperature leads to an increase in phenol [39]. Previous research showed a highest content of phenol (2.34 mg.g ${ }^{-1}$, extracted by water) in this species [2]. Choi et al. [9] also reported that the highest total phenolic amounts in the butanol extract $\left(9.97 \pm 0.73 \mathrm{mg} \cdot \mathrm{mL}^{-1}\right)$. Compared with their reports, however, we got a satisfactory result. The extract methods (solution) and culture condition probably contribute to those difference among those studies [2,9]. A main secondary metabolite, total phenol, has a great antioxidant potential, thereby enhancing resistance to abiotic stresses in plants [43]. Thus, a higher level of total phenol reduces the accumulation of ROS in cells and accelerates the growth of seedlings under TB (Figure 1).

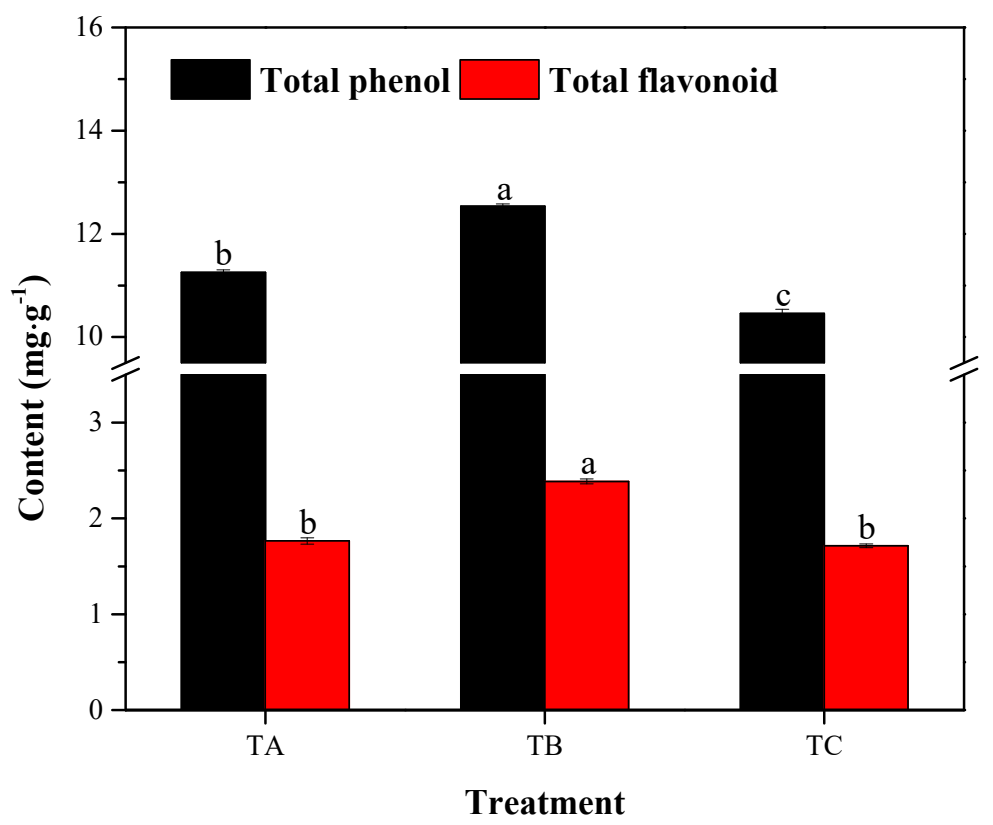

Figure 2. Contents of total phenol and flavonoid accumulated in leaves of A. triphylla (Thunb.) A.DC. seedlings grown under different temperature regimes after six weeks of cultivation. TA, $20 / 20{ }^{\circ} \mathrm{C}$ (day/night); $\mathrm{TB}, 25 / 15^{\circ} \mathrm{C}$; $\mathrm{TC}, 20 / 15^{\circ} \mathrm{C}$. Data is presented as the mean \pm standard error $(n=3)$. The different letters $(a, b$, and $c)$ indicate significant differences $(p<0.05)$ among treatments. 
On the other hand, the obtained results showed the highest content of total flavonoid was in seedlings under TB $\left(2.4 \pm 0.0 \mathrm{mg} \cdot \mathrm{g}^{-1}\right)$ (Figure 2$), 33 \%$ higher than that for seedlings under TA $\left(1.8 \pm 0.0 \mathrm{mg} \cdot \mathrm{g}^{-1}\right)$ and $41 \%$ higher than that for seedlings in TC $\left(1.7 \pm 0.0 \mathrm{mg} \cdot \mathrm{g}^{-1}\right)$. The feature of total flavonoids among those three treatment are similar with total phenols (Figure 2). The reason for this is that elevated temperatures contribute to increases in secondary metabolites such as phenol and flavonoid in the plant tissues [40]. Contents of total flavonoid in our research are slightly higher than previous results $\left(1.17 \mathrm{mg} \cdot \mathrm{g}^{-1}\right)$ [2]. As one of medicinal compounds which play a role in curing many kinds of diseases, flavonoids in plants are also capable of scavenging ROS and maintaining a healthy status of seedlings [2], which benefit the growth of seedlings in TB (Figure 1). Therefore, TB can be the optimum temperature regime to increase the growth of seedlings and medicinal value of A. triphylla.

In the future, further attentions should be paid to the accumulation of total phenol and flavonoid over a long term, since it fluctuates with the season and the age of individuals [71,72]. Because our experiment only operated for 6 weeks, effects over the long term will be trialed in the near future, in order to confirm the optimal cultivation cycles and harvest period.

\subsection{Physiological Responses of Seedlings under Various Temperature Conditions}

Under adverse ambient temperatures, including heat or chilling, ROS is rapidly accumulated, resulting in oxidative stresses and causes damages to cell structure and disorders in plant physiology $[27,73,74]$. Thus, the level of ROS in plants implies the degree of ROS-induced oxidative stresses. As a major ROS, $\mathrm{H}_{2} \mathrm{O}_{2}$ serves as an indicator of stress [75]. In our research, content of $\mathrm{H}_{2} \mathrm{O}_{2}$ in seedlings under TB was $5.11 \pm 0.06 \mu \mathrm{mol} \cdot \mathrm{g}^{-1} \mathrm{FW}$ (fresh weight), significantly lower than for seedlings in TA $\left(6.02 \pm 0.06 \mu \mathrm{mol} \cdot \mathrm{g}^{-1} \mathrm{FW}\right)$ or TC $\left(11.34 \pm 0.05 \mu \mathrm{mol} \cdot \mathrm{g}^{-1} \mathrm{FW}\right)$ (Figure 3). A lower $\mathrm{H}_{2} \mathrm{O}_{2}$ content in seedlings under TB implied that seedlings had less stresses and grew better than seedlings in the other treatments.

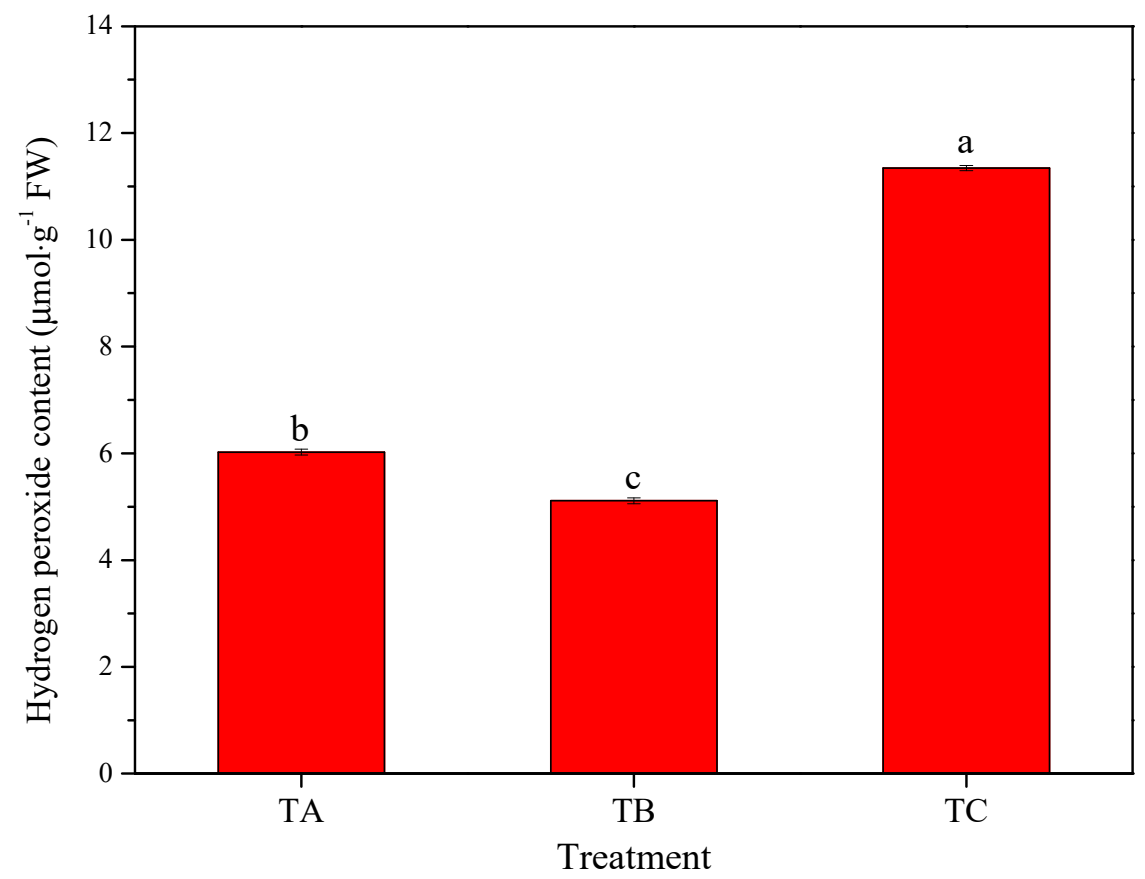

Figure 3. Hydrogen peroxide content in leaves of $A$. triphylla (Thunb.) A.DC. seedlings grown under different temperature regimes after six weeks of cultivation. TA, $20 / 20{ }^{\circ} \mathrm{C}$ (day/night); $\mathrm{TB}, 25 / 15{ }^{\circ} \mathrm{C}$; TC, $20 / 15^{\circ} \mathrm{C}$. Data is presented as the mean \pm standard error $(n=3)$. The different letters $(\mathrm{a}, \mathrm{b}$, and $\mathrm{c})$ indicate significant differences $(p<0.05)$ among treatments. 
To reduce the excessive ROS, plants have developed multiple strategies to scavenge ROS, including the antioxidant enzyme system $[28,76]$. In our study, the activities of antioxidant enzymes in leaves, such as SOD, APX, and GPX, were consistent with the level of $\mathrm{H}_{2} \mathrm{O}_{2}$ (Figure 4). The activity of SOD for seedlings in TC was $5.37 \pm 0.33 \mathrm{U} \cdot \mathrm{mg}^{-1}$ protein, significantly higher than that for seedlings in TA $\left(1.60 \pm 0.14 \mathrm{U} \cdot \mathrm{mg}^{-1}\right.$ protein $)$ and TB $\left(1.34 \pm 0.35 \mathrm{U} \cdot \mathrm{mg}^{-1}\right.$ protein). Because the function of SOD is to dismutase the superoxide radical into $\mathrm{H}_{2} \mathrm{O}_{2}$, an increase in the activity of SOD for seedlings in TC promotes the production and accumulation of $\mathrm{H}_{2} \mathrm{O}_{2}$ in cells (Figure 3). The endogenous $\mathrm{H}_{2} \mathrm{O}_{2}$ generated by SOD will be detoxified into $\mathrm{H}_{2} \mathrm{O}$ and $\mathrm{O}_{2}$ by CAT, or into only $\mathrm{H}_{2} \mathrm{O}$ by GPX or APX. Because of the low $\mathrm{H}_{2} \mathrm{O}_{2}$ content in seedlings under TB, the activities of CAT (10.93 \pm $0.58 \mathrm{U} \cdot \mathrm{mg}^{-1}$ protein $)$, APX $\left(0.14 \pm 0.08 \mathrm{U} \cdot \mathrm{mg}^{-1}\right.$ protein $)$, and GPX $\left(2.31 \pm 0.35 \mathrm{U} \cdot \mathrm{mg}^{-1}\right.$ protein $)$ in seedlings under TB showed the lowest values when compared with seedlings in the other treatments (Figure 4), indicating less stresses and a better growth status. Similarly, Boo et al. [29] found that at low temperatures, lettuce leaves possess a high level of antioxidant and enzymatic status. Although antioxidant enzymes in seedlings under TA or TC showed high activities, seedlings consumed more energy to resist stresses from unsuitable temperatures, which does not benefit the growth and the accumulation of secondary metabolites. Therefore, growth and secondary metabolites for seedlings in TB were better than that for those in TA and TC (Figures 1 and 2).
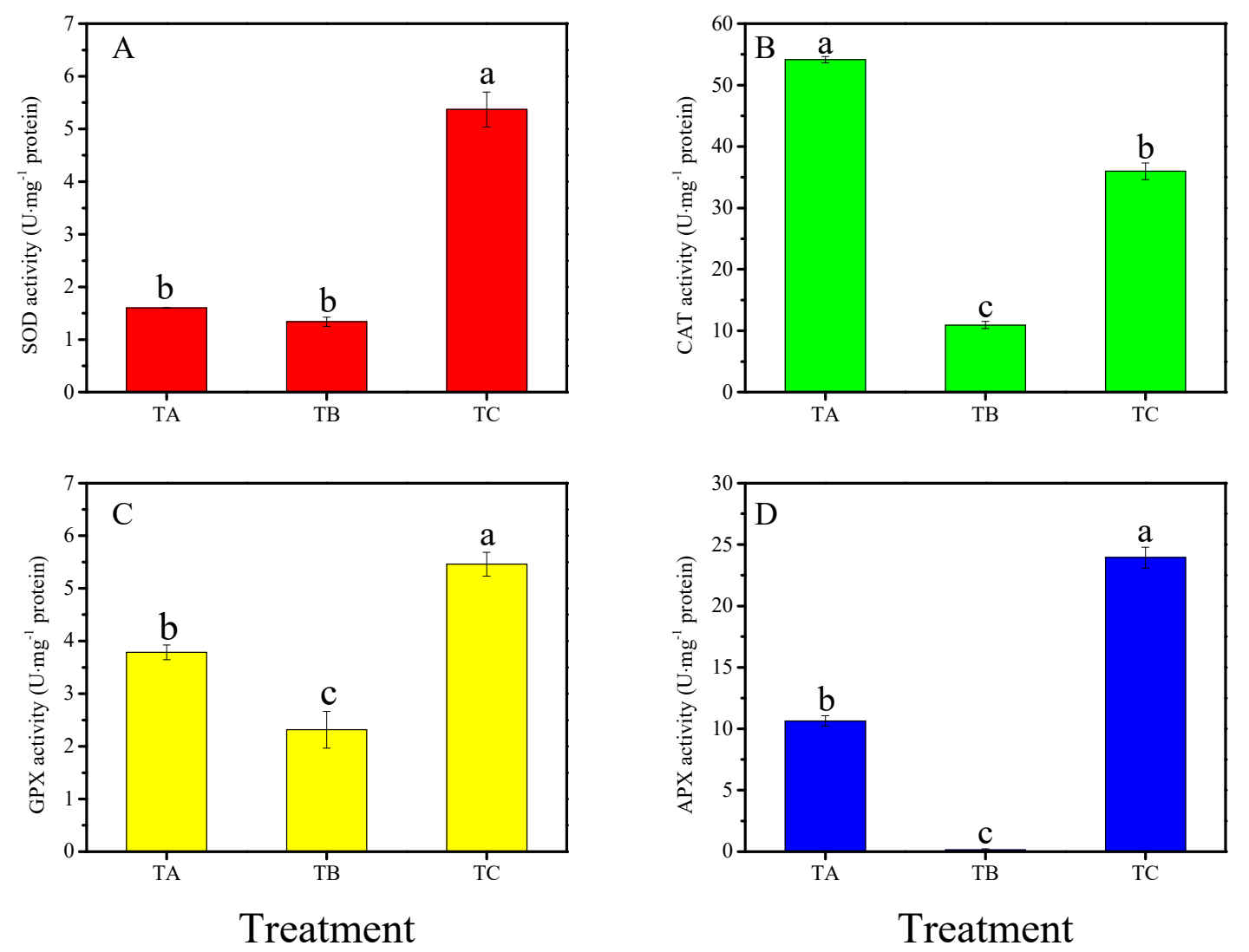

Figure 4. Activities of superoxide dismutase (A), catalase (B), glutathione reductase (GPX) (C), and ascorbate peroxidase (D) in leaves of $A$. triphylla (Thunb.) A.DC. seedlings grown under different temperature regimes after six weeks of cultivation. TA, $20 / 20{ }^{\circ} \mathrm{C}$ (day/night); $\mathrm{TB}, 25 / 15{ }^{\circ} \mathrm{C}$; $\mathrm{TC}$, $20 / 15^{\circ} \mathrm{C}$. SOD, superoxide dismutase; CAT, catalase; GPX, glutathione reductase; and APX, ascorbate peroxidase. Data is presented as the mean \pm standard error $(n=3)$. The different letters $(\mathrm{a}, \mathrm{b}$, and $\mathrm{c})$ indicate significant differences $(p<0.05)$ among treatments. 
Isozymes are enzymes that differ in amino acid sequence but catalyze the same chemical reaction with different kinetic parameters [49,77]. The existence of isozymes is of great importance in plant cells since these isozymes ensure a fine-tuning of metabolic regulation to control plant growth, development, and defense responses. Thus research into the expression of antioxidant isozymes would be helpful in revealing the physiological response of antioxidant enzymes and mechanisms of ROS scavenging under different temperature regimes. As a signaling molecule, endogenous $\mathrm{H}_{2} \mathrm{O}_{2}$ at a low level $\left(\mathrm{nmol} \cdot \mathrm{g}^{-1}\right)$ plays a role in seedling growth and development and in mediating tolerance by inducing antioxidant enzymes [78,79]. However, high concentration of $\mathrm{H}_{2} \mathrm{O}_{2}$ has a negative impact and induces an excessive expression of antioxidant isozymes. As shown in Figure 5A, four bands of SOD isozymes were identified in all three treatments. However, the intensity was quite different among treatments (Figure 5E). The intensity of almost all SOD isozymes was the lowest in TB, supporting the result of SOD activity above (Figure 4A). However, the intensity of SOD2 was the lowest in TA and the highest in TC. Tian et al. [37] also showed a difference expression of four SOD isozymes under $42 / 32{ }^{\circ} \mathrm{C}$ and $28 / 18{ }^{\circ} \mathrm{C}$ with or without spermidine foliar spraying. Differences in expressions of SOD isozymes results in a difference in the production of $\mathrm{H}_{2} \mathrm{O}_{2}$ (Figure 3), which can be then decomposed by CAT, GPX, or APX subsequently. In our research, there was only one form of CAT enzyme found in all three treatments. Relative activity of CAT in TB and TC decreased about $73.2 \%$ and $27.0 \%$, respectively, compared with that in TA (Figure 5F), which is in accordance with the results from Figure 4B. Previous research confirmed six isozymes of CAT in Arabidopsis thaliana (L.) Heynh leaves, coded by three homologous genes [80]. Only one isozyme in our study may be due to a high turnover rate in plant organ and a much lower affinity with $\mathrm{H}_{2} \mathrm{O}_{2}$ compared with APX and GPX [81]. Another reason probably is that moderate temperature regime reduced expression of CAT isozymes [82]. Meanwhile, three forms of GPX isozymes were separated in all three treatment (Figure 5C). The intensity of GPX3 in TC was greatly increased, and about 2.41-fold or 2.42-fold higher than that in TA or TB (Figure 5G). Besides, a decrease in GPX1 or GPX2 intensities was found in TB than that in TA or TC, respectively. A similar result reported by Kang et al. [78] was that activities of GPX isozymes in foliar application of $\mathrm{H}_{2} \mathrm{O}_{2}$ was lower than those under heat treatment. In addition, two forms of APX isozymes were identified to directly detoxify $\mathrm{H}_{2} \mathrm{O}_{2}$ in our study (Figure 5D). The expression of APX1 was largely higher in TA than that in TB (1.59-fold) and TC (1.67-fold). Slightly differently from APX1, the activity of APX2 was dramatically decreased in TB than TA and TC. It was about $24 \%$ of that in TA or $18 \%$ of that in TC. As a high-efficient antioxidant enzyme, APX possesses a powerful ability in scavenging $\mathrm{H}_{2} \mathrm{O}_{2}$ to maintain homeostasis in plant cells [81]. Our data imply that multiple isozymes of APX come into play in this process. For example, Jaiswal et al. [82] showed a different expression of APX isozymes between healthy and infected pumpkin leaves by native PAGE. Ahn et al. [83] found a diverse expression of APX isozymes among cultivars of apple. Overall, relative lower activities of antioxidant isozymes were maintained in TB than that of TA and TC, even though there are some variations among the expression patterns of different antioxidant isozymes (Figure 5), which was also in line with $\mathrm{H}_{2} \mathrm{O}_{2}$ level and antioxidant enzymes activities (Figures 3 and 4). 
A

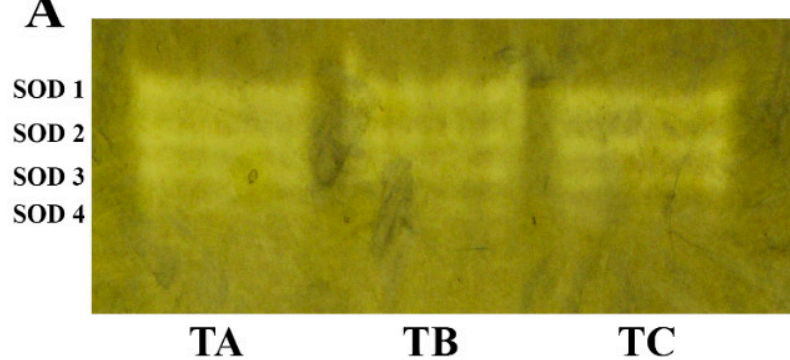

B

CAT

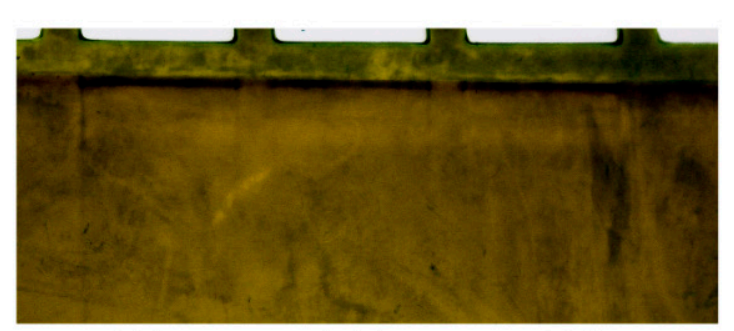

TA

C

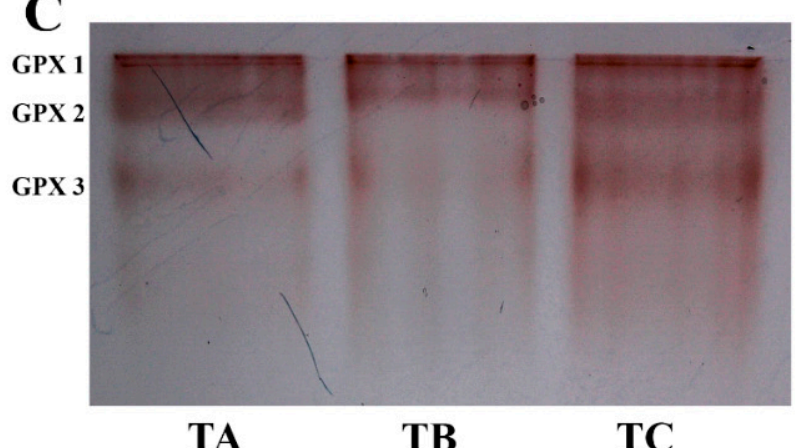

TA

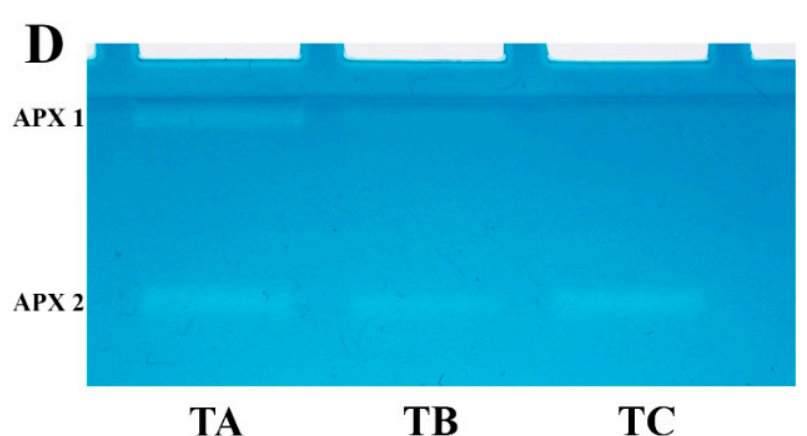

$\mathbf{E}$

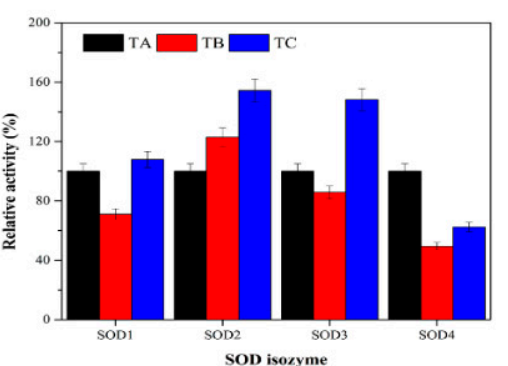

F

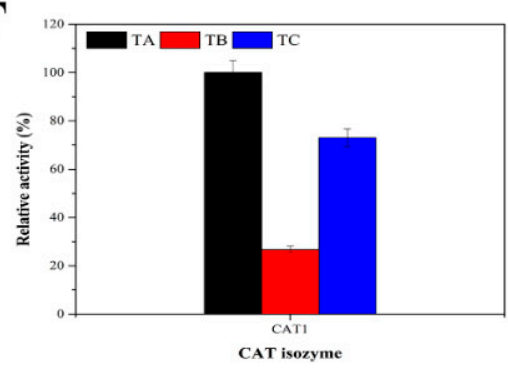

G

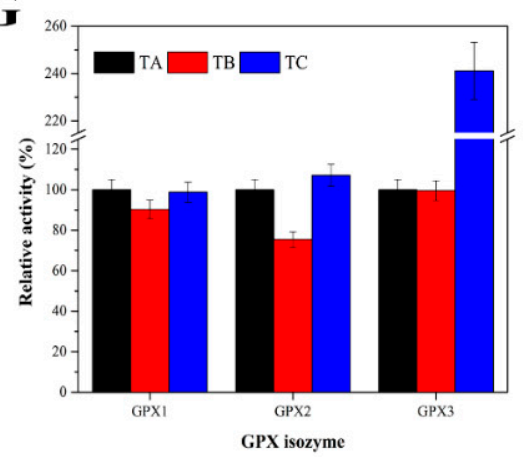

H

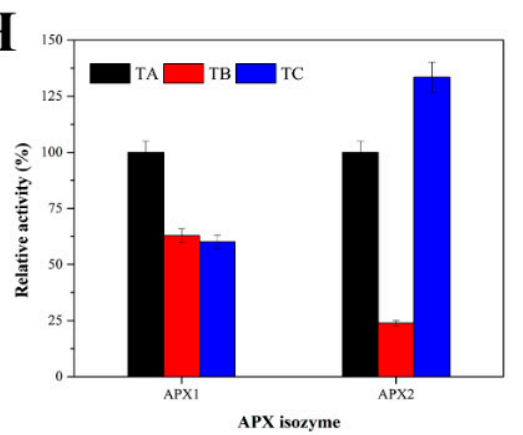

Figure 5. Native-PAGE (polyacrylamide gel electrophoresis) analysis of antioxidant isozymes expressions (A-D) and relative activities (E-H) in leaves of $A$. triphylla (Thunb.) A.DC. seedlings grown under different temperature regimes (TA, $20 / 20{ }^{\circ} \mathrm{C}$ (day/night); $\mathrm{TB}, 25 / 15^{\circ} \mathrm{C}$; and $\mathrm{TC}, 20 / 15^{\circ} \mathrm{C}$ ) after six weeks of cultivation. SOD, superoxide dismutase; CAT, catalase; GPX, glutathione reductase; and APX, ascorbate peroxidase.

\section{Conclusions}

In conclusion, our results demonstrated that $A$. triphylla seedlings grown under $25 / 15^{\circ} \mathrm{C}$ (TB) showed the largest growth parameters, such as root number, stem diameter, and biomass. Besides, this temperature regime promoted primary and secondary metabolism of seedlings, including synthesizing more contents of soluble sugar, soluble protein, total protein, and total flavonoid. Moreover, both $\mathrm{H}_{2} \mathrm{O}_{2}$ content and antioxidant enzyme activities such as SOD, CAT, GPX, and 
APX, were also the lowest in seedlings under TB, suggesting less oxidative stresses. Native PAGE analysis further confirmed low activities of antioxidant isozymes in TB treatment. Therefore, our research strongly proved that $25 / 15^{\circ} \mathrm{C}$ (day/night) is an ideal temperature regime for the growth and physiological development of $A$. triphylla seedlings.

Since $A$. triphylla is of great importance, with high medicinal, edible, and ornamental values, more studies should be carried out in the future. First of all, cultivation conditions such as light, water, and nutrition solution, should be optimized in order to obtain high quality of seedlings. Second, application of elicitors should be considered to improve secondary metabolites including phenols and flavonoids. Importantly, the reasons why those elicitors work should be clarified at a gene and protein level. Last but not least, the micropropagation technique should be attempted for the purpose of obtaining more material in a very short time.

Supplementary Materials: The following are available online at http:/ /www.mdpi.com/2073-4395/8/9/173/s1, Table S1: Shoot and root length, no. of leaves, and water content in A. triphylla seedlings under different treatment regimes.

Author Contributions: Conceptualization, Y.L., X.R., and B.R.J.; Funding acquisition, B.R.J.; Investigation, Y.L., X.R., H.K.J., and H.W.; Project administration, X.R. and B.R.J.; Supervision, H.K.J.; Writing-original draft, Y.L.; Writing-review and editing, Y.L., X.R., and B.R.J.

Funding: This research was funded by the Korea Institute of Planning and Evaluation for Technology in Food, Agriculture, Forestry and Fisheries (Project No. 116057-03). Y.L., X.R., H.K.J., and H.W. were supported by a scholarship from the BK21 Plus Program, Ministry of Education, Republic of Korea.

Conflicts of Interest: The authors declare no conflict of interest.

\section{References}

1. Gorovoi, P.G.; Ponomarchuk, G.I.; Strigina, L.I. A chemotaxonomic study on russian far-eastern Campanulaceae. Phytochemistry 1971, 10, 2419-2423. [CrossRef]

2. Kim, J.H.; Hong, J.Y.; Shin, S.R.; Yoon, K.Y. Comparison of antioxidant activity in wild plant (Adenophora triphylla) leaves and roots as a potential source of functional foods. Int. J. Food Sci. Nutr. 2009, 60, 150-161. [CrossRef] [PubMed]

3. Lee, S.E.; Lee, E.H.; Lee, T.J.; Kim, S.W.; Kim, B.H. Anti-obesity effect and action mechanism of Adenophora triphylla root ethanol extract in C57BL/6 obese mice fed a high-fat diet. Biosci. Biotechnol. Biochem. 2013, 77, 544-550. [CrossRef] [PubMed]

4. Chun, J.; Kang, M.; Kim, Y.S. A triterpenoid saponin from Adenophora triphylla var. japonica suppresses the growth of human gastric cancer cells via regulation of apoptosis and autophagy. Tumor Biol. 2014, 35, 12021-12030.

5. Ahn, E.K.; Oh, J.S. Lupenone isolated from Adenophora triphylla var. japonica extract inhibits adipogenic differentiation through the downregulation of PPAR $\gamma$ in 3T3-L1 cells. Phytother. Res. 2013, 27, 761-766. [PubMed]

6. Konno, C.; Saito, T.; Oshima, Y.; Hikino, H.; Kabuto, C. Structure of methyl adenophorate and triphyllol, triterpenoids of Adenophora triphylla var. japonica roots. Planta Med. 1981, 42, 268-274. [CrossRef] [PubMed]

7. Park, Y.K.; Yoo, H.H.; Baek, S.H.; Park, M.; Park, J.; Lee, S.; Kim, C.; Lee, K. Quality control of Adenophorae Radix. Korean J. Pharmacogenet. 2003, 34, 10-13. (In Korean)

8. Asano, N.; Nishida, M.; Miyauchi, M.; Ikeda, K.; Yamamoto, M.; Kizu, H.; Kameda, Y.; Watson, A.A.; Nash, R.J.; Fleet, G.W.J. Polyhydroxylated pyrrolidine and piperidine alkaloids from Adenophora triphylla var. japonica (Campanulaceae). Phytochemistry 2000, 53, 379-382. [CrossRef]

9. Choi, H.J.; Chung, M.J.; Ham, S.S. Antiobese and hypocholesterolaemic effects of an Adenophora triphylla extract in HepG2 cells and high fat diet-induced obese mice. Food Chem. 2010, 119, 437-444. [CrossRef]

10. Kang, M.; Ha, I.J.; Chun, J.; Kang, S.S.; Kim, Y.S. Separation of two cytotoxic saponins from the roots of Adenophora triphylla var. japonica by high-speed counter-current chromatography. Phytochem. Anal. 2013, 24, 148-154. [PubMed] 
11. Vishwakarma, K.; Upadhyay, N.; Kumar, N.; Yadav, G.; Singh, J.; Mishra, R.K.; Kumar, V.; Verma, R.; Upadhyay, R.G.; Pandey, M.; et al. Abscisic acid signaling and abiotic stress tolerance in plants: A review on current knowledge and future prospects. Front. Plant Sci. 2017, 8, 161. [CrossRef] [PubMed]

12. Garruna-Hernandez, R.; Orellana, R.; Larque-Saavedra, A.; Canto, A. Understanding the physiological responses of a tropical crop (Capsicum chinense Jacq.) at high temperature. PLoS ONE 2014, 9, e111402. [CrossRef] [PubMed]

13. Guevara-Figueroa, T.; Lopez-Hernandez, L.; Lopez, M.G.; Hurtado, M.D.D.; Vazquez-Barrios, M.E.; Guevara-Olvera, L.; Gonzalez, R.G.G.; Rivera-Pastrana, D.M.; Torres-Robles, H.; Mercado-Silva, E.M. Conditioning garlic "seed" cloves at low temperature modifies plant growth, sugar, fructan content, and sucrose sucrose fructosyl transferase (1-SST) expression. Sci. Hortic. 2015, 189, 150-158. [CrossRef]

14. Szymanska, R.; Slesak, I.; Orzechowska, A.; Kruk, J. Physiological and biochemical responses to high light and temperature stress in plants. Environ. Exp. Bot. 2017, 139, 165-177. [CrossRef]

15. Xu, X.X.; Hu, Q.; Yang, W.N.; Jin, Y. The roles of call wall invertase inhibitor in regulating chilling tolerance in tomato. BMC Plant Biol. 2017, 17, 195. [CrossRef] [PubMed]

16. Li, L.; Li, J.; Gao, Q.; Chen, J.X. Effects of day and night temperature difference on growth, development, yield and fruit quality of tomatoes. Chin. J. Appl. Ecol. 2015, 26, 2700-2706. (In Chinese)

17. Si, Y.P.; Heins, R.D. Influence of day and night temperatures on sweet pepper seedling development. J. Am. Soc. Hortic. Sci. 1996, 121, 699-704.

18. Yang, Z.Q.; Li, Y.S.; Li, P.; Zhang, F.M.; Thomas, B.W. Effect of difference between day and night temperature on tomato (Lycopersicon esculentum Mill.) root activity and low molecular weight organic acid secretion. Soil Sci. Plant Nutr. 2016, 62, 423-431. [CrossRef]

19. Ribeiro, P.R.; Zanotti, R.F.; Deflers, C.; Fernandez, L.G.; de Castro, R.D.; Ligterink, W.; Hilhorst, H.W.M. Effect of temperature on biomass allocation in seedlings of two contrasting genotypes of the oilseed crop Ricinus communis. J. Plant Physiol. 2015, 185, 31-39. [CrossRef] [PubMed]

20. Cheng, W.; Sakai, H.; Yagi, K.; Hasegawa, T. Interactions of elevated $\mathrm{CO}_{2}$ and night temperature on rice growth and yield. Agric. For. Meteorol. 2009, 149, 51-58. [CrossRef]

21. Ryu, S.; Han, H.H.; Jeong, J.H.; Kwon, Y.; Han, J.H.; Do, G.R.; Choi, I.M.; Lee, H.J. Night temperatures affect fruit coloration and expressions of anthocyanin biosynthetic genes in 'Hongro' apple fruit skins. Eur. J. Hortic. Sci. 2017, 82, 232-238. [CrossRef]

22. Gaiotti, F.; Pastore, C.; Filippetti, I.; Lovat, L.; Belfiore, N.; Tomasi, D. Low night temperature at veraison enhances the accumulation of anthocyanins in corvina grapes (Vitis vinifera L.). Sci. Rep. 2018, 8, 1-13. [CrossRef] [PubMed]

23. Zhang, J.; Jiang, F.W.; Yang, P.; Li, J.; Yan, G.J.; Hu, L.Y. Responses of canola (Brassica napus L.) cultivars under contrasting temperature regimes during early seedling growth stage as revealed by multiple physiological criteria. Acta Physiol. Plant. 2015, 37, 7. [CrossRef]

24. Antoniou, C.; Savvides, A.; Christou, A.; Fotopoulos, V. Unravelling chemical priming machinery in plants: The role of reactive oxygen-nitrogen-sulfur species in abiotic stress tolerance enhancement. Curr. Opin. Plant Biol. 2016, 33, 101-107. [CrossRef] [PubMed]

25. Li, J.S.; Jia, H.L.; Wang, J.; Cao, Q.H.; Wen, Z.C. Hydrogen sulfide is involved in maintaining ion homeostasis via regulating plasma membrane $\mathrm{Na}^{+} / \mathrm{H}^{+}$antiporter system in the hydrogen peroxide-dependent manner in salt-stress Arabidopsis thaliana root. Protoplasma 2014, 251, 899-912. [CrossRef] [PubMed]

26. Zhao, M.G.; Tian, Q.Y.; Zhang, W.H. Nitric oxide synthase-dependent nitric oxide production is associated with salt tolerance in Arabidopsis. Plant Physiol. 2007, 144, 206-217. [CrossRef] [PubMed]

27. Muneer, S.; Jeong, B.R. Proteomic analysis of salt-stress responsive proteins in roots of tomato (Lycopersicon esculentum L.) plants towards silicon efficiency. Plant Growth Regul. 2015, 77, 133-146. [CrossRef]

28. Almeselmani, M.; Deshmukh, P.S.; Sairam, R.K.; Kushwaha, S.R.; Singh, T.P. Protective role of antioxidant enzymes under high temperature stress. Plant Sci. 2006, 171, 382-388. [CrossRef] [PubMed]

29. Boo, H.O.; Heo, B.G.; Gorinstein, S.; Chon, S.U. Positive effects of temperature and growth conditions on enzymatic and antioxidant status in lettuce plants. Plant Sci. 2011, 181, 479-484. [CrossRef] [PubMed]

30. Cao, H.X.; Sun, C.X.; Shao, H.B.; Lei, X.T. Effects of low temperature and drought on the physiological and growth changes in oil palm seedlings. Afr. J. Biotechnol. 2011, 10, 2630-2637. 
31. Gao, J.J.; Li, T.; Yu, X.C. Gene expression and activities of sod in cucumber seedlings were related with concentrations of $\mathrm{Mn}^{2+}, \mathrm{Cu}^{2+}$, or $\mathrm{Zn}^{2+}$ under low temperature stress. Agric. Sci. China 2009, 8, 678-684. [CrossRef]

32. Meena, M.; Zehra, A.; Dubey, M.K.; Aamir, M.; Gupta, V.K.; Upadhyay, R.S. Comparative evaluation of biochemical changes in tomato (Lycopersicon esculentum Mill.) infected by Alternaria alternata and its toxic metabolites (TeA, AOH, and AME). Front. Plant Sci. 2016, 7, 1408. [CrossRef] [PubMed]

33. Shah, K.; Nahakpam, S. Heat exposure alters the expression of SOD, POD, APX and CAT isozymes and mitigates low cadmium toxicity in seedlings of sensitive and tolerant rice cultivars. Plant Physiol. Biochem. 2012, 57, 106-113. [CrossRef] [PubMed]

34. Dewir, Y.H.; Chakrabarty, D.; Ali, M.B.; Hahn, E.J.; Paek, K.Y. Lipid peroxidation and antioxidant enzyme activities of Euphorbia milii hyperhydric shoots. Environ. Exp. Bot. 2006, 58, 93-99. [CrossRef]

35. Covian, R.; Chess, D.; Balaban, R.S. Continuous monitoring of enzymatic activity within native electrophoresis gels: Application to mitochondrial oxidative phosphorylation complexes. Anal. Biochem. 2012, 431, 30-39. [CrossRef] [PubMed]

36. Wittig, I.; Braun, H.P.; Schägger, H. Blue native PAGE. Nat. Protoc. 2006, 1, 418. [CrossRef] [PubMed]

37. Tian, J.; Wang, L.P.; Yang, Y.J.; Sun, J.; Guo, S.R. Exogenous spermidine alleviates the oxidative damage in cucumber seedlings subjected to high temperatures. J. Am. Soc. Hortic. Sci. 2012, 137, 11-19.

38. Wang, Y.Q.; Li, L.; Cui, W.T.; Xu, S.; Shen, W.B.; Wang, R. Hydrogen sulfide enhances alfalfa (Medicago sativa) tolerance against salinity during seed germination by nitric oxide pathway. Plant Soil 2012, 351, 107-119. [CrossRef]

39. Wang, S.Y.; Zheng, W. Effect of plant growth temperature on antioxidant capacity in strawberry. J. Agric. Food Chem. 2001, 49, 4977-4982. [CrossRef] [PubMed]

40. Zhao, Y.H.; Jia, X.; Wang, W.K.; Liu, T.; Huang, S.P.; Yang, M.Y. Growth under elevated air temperature alters secondary metabolites in Robinia pseudoacacia L. Seedlings in Cd- and Pb-contaminated soils. Sci. Total Environ. 2016, 565, 586-594. [CrossRef] [PubMed]

41. Hura, K.; Hura, T.; Rapacz, M.; Plazek, A. Effects of low-temperature hardening on the biochemical response of winter oilseed rape seedlings inoculated with the spores of Leptosphaeria maculans. Biologia 2015, 70, 1011-1018. [CrossRef]

42. Manivannan, A.; Soundararajan, P.; Park, Y.G.; Jeong, B.R. In vitro propagation, phytochemical analysis, and evaluation of free radical scavenging property of Scrophularia kakudensis Franch tissue extracts. BioMed Res. Int. 2015, 2015. [CrossRef] [PubMed]

43. Reddy, N.S.; Navanesan, S.; Sinniah, S.K.; Wahab, N.A.; Sim, K.S. Phenolic content, antioxidant effect and cytotoxic activity of leea indica leaves. BMC Complement. Altern. Med. 2012, 12, 128. [CrossRef] [PubMed]

44. Bradford, M.M. Rapid and sensitive method for quantitation of microgram quantities of protein utilizing principle of protein-dye binding. Anal. Biochem. 1976, 72, 248-254. [CrossRef]

45. López, S.; Maroto, J.V.; San Bautista, A.; Pascual, B.; Alagarda, J. Differences in carbohydrate content of waiting-bed strawberry plants during development in the nursery. Sci. Hortic. 2002, 94, 53-62. [CrossRef]

46. Manivannan, A.; Soundararajan, P.; Park, Y.G.; Jeong, B.R. Chemical elicitor-induced modulation of antioxidant metabolism and enhancement of secondary metabolite accumulation in cell suspension cultures of Scrophularia kakudensis Franch. Int. J. Mol. Sci. 2016, 17, 399. [CrossRef] [PubMed]

47. Manivannan, A.; Soundararajan, P.; Muneer, S.; Ko, C.H.; Jeong, B.R. Silicon mitigates salinity stress by regulating the physiology, antioxidant enzyme activities, and protein expression in Capsicum annuum 'bugwang'. BioMed Res. Int. 2016, 2016. [CrossRef] [PubMed]

48. Soundararajan, P.; Manivannan, A.; Cho, Y.S.; Jeong, B.R. Exogenous supplementation of silicon improved the recovery of hyperhydric shoots in Dianthus caryophyllus L. by stabilizing the physiology and protein expression. Front. Plant Sci. 2017, 8, 738. [CrossRef] [PubMed]

49. Chakrabarty, D.; Park, S.Y.; Ali, M.B.; Shin, K.S.; Paek, K.Y. Hyperhydricity in apple: Ultrastuctural and physiological aspects. Tree Physiol. 2006, 26, 377-388. [CrossRef] [PubMed]

50. Manivannan, A.; Jana, S.; Soundararajan, P.; Ko, C.H.; Jeong, B.R. Antioxidant enzymes metabolism and cellular differentiation during the developmental stages of somatic embryogenesis in 'Torilis japonica' (Houtt.) DC. Plant Omics 2015, 8, 461. 
51. Gallo-Oller, G.; Ordoñez, R.; Dotor, J. A new background subtraction method for western blot densitometry band quantification through image analysis software. J. Immunol. Methods 2018, 457, 1-5. [CrossRef] [PubMed]

52. Sønsteby, A.; Solhaug, K.A.; Heide, O.M. Functional growth analysis of 'Sonata' strawberry plants grown under controlled temperature and daylength conditions. Sci. Hortic. 2016, 211, 26-33. [CrossRef]

53. Arena, M.E.; Radice, S. Shoot growth and development of Berberis buxifolia Lam. in Tierra del Fuego (Patagonia). Sci. Hortic. 2014, 165, 5-12. [CrossRef]

54. Cookson, S.J.; Hevin, C.; Donnart, M.; Ollat, N. Grapevine rootstock effects on scion biomass are not associated with large modifications of primary shoot growth under nonlimiting conditions in the first year of growth. Funct. Plant Biol. 2012, 39, 650-660. [CrossRef]

55. Lin, S.Y.; Liao, Y.Y.; Roan, S.F.; Chen, I.Z.; Chen, P.A. Growth of noni fruits (Morinda citrifolia L.) and accumulation of phenolic compounds during fruit development. Sci. Hortic. 2014, 178, 168-174. [CrossRef]

56. Jing, P.; Wang, D.; Zhu, C.; Chen, J. Plant physiological, morphological and yield-related responses to night temperature changes across different species and plant functional types. Front. Plant Sci. 2016, 7, 1774. [CrossRef] [PubMed]

57. Loka, D.A.; Oosterhuis, D.M. Increased night temperatures during cotton's early reproductive stage affect leaf physiology and flower bud carbohydrate content decreasing flower bud retention. J. Agron. Crop Sci. 2016, 202, 518-529. [CrossRef]

58. Lesjak, J.; Calderini, D.F. Increased night temperature negatively affects grain yield, biomass and grain number in Chilean quinoa. Front. Plant Sci. 2017, 8, 352. [CrossRef] [PubMed]

59. Yuan, X.K. Effect of day/night temperature difference on chlorophyII content, photosynthesis and fluorescence parameters of tomato at fruit stage. Photosynthetica 2016, 54, 475-477. [CrossRef]

60. Criddle, R.S.; Smith, B.N.; Hansen, L.D. A respiration based description of plant growth rate responses to temperature. Planta 1997, 201, 441-445. [CrossRef]

61. Hansen, L.D.; Thomas, N.R.; Arnholdt-Schmitt, B. Temperature responses of substrate carbon conversion efficiencies and growth rates of plant tissues. Physiol. Plant. 2009, 137, 446-458. [CrossRef] [PubMed]

62. Krasensky, J.; Jonak, C. Drought, salt, and temperature stress-induced metabolic rearrangements and regulatory networks. J. Exp. Bot. 2012, 63, 1593-1608. [CrossRef] [PubMed]

63. Uemura, M.; Steponkus, P.L. Modification of the intracellular sugar content alters the incidence of freeze-induced membrane lesions of protoplasts isolated from Arabidopsis thaliana leaves. Plant Cell Environ. 2003, 26, 1083-1096. [CrossRef]

64. Cao, Y.Y.; Yang, M.T.; Li, X.; Zhou, Z.Q.; Wang, X.J.; Bai, J.G. Exogenous sucrose increases chilling tolerance in cucumber seedlings by modulating antioxidant enzyme activity and regulating proline and soluble sugar contents. Sci. Hortic. 2014, 179, 67-77. [CrossRef]

65. Rosa, M.; Prado, C.; Podazza, G.; Interdonato, R.; González, J.A.; Hilal, M.; Prado, F.E. Soluble sugars-metabolism, sensing and abiotic stress: A complex network in the life of plants. Plant Signal. Behav. 2009, 4, 388-393. [CrossRef] [PubMed]

66. Chen, J.; Wu, X.; Yao, X.; Zhu, Z.; Xu, S.; Zha, D. Exogenous 6-benzylaminopurine confers tolerance to low temperature by amelioration of oxidative damage in eggplant (Solanum melongena L.) seedlings. Rev. Bras. Bot. 2016, 39, 409-416. [CrossRef]

67. De Sousa, D.P.F.; Braga, B.B.; Gondim, F.A.; Gomes-Filho, E.; Martins, K.; de Brito, P.O.B. Increased drought tolerance in maize plants induced by $\mathrm{H}_{2} \mathrm{O}_{2}$ is closely related to an enhanced enzymatic antioxidant system and higher soluble protein and organic solutes contents. Theor. Exp. Plant Physiol. 2016, 28, 297-306. [CrossRef]

68. Zhou, Z.; Ma, H.; Liang, K.; Huang, G.; Pinyopusarerk, K. Improved tolerance of teak (Tectona grandis L.f.) seedlings to low-temperature stress by the combined effect of arbuscular mycorrhiza and paclobutrazol. J. Plant Growth Regul. 2012, 31, 427-435. [CrossRef]

69. Shishido, Y.; Seyama, N.; Imada, S.; Hori, Y. Carbon budget in tomato plants as affected by night temperature evaluated by steady state feeding with ${ }^{14} \mathrm{CO}_{2}$. Ann. Bot. 1989, 63, 357-367. [CrossRef]

70. Warner, D.A.; Holaday, A.S.; Burke, J.J. Response of carbon metabolism to night temperature in cotton. Agron. J. 1995, 87, 1193-1197. [CrossRef] 
71. Peschel, W.; Kump, A.; Zomborszki, Z.P.; Pfosser, M.; Kainz, W.; Csupor, D. Phenylpropenoid content in high-altitude cultivated Rhodiola rosea L. provenances according to plant part, harvest season and age. Ind. Crop. Prod. 2018, 111, 446-456. [CrossRef]

72. Cezarotto, V.S.; Giacomelli, S.R.; Vendruscolo, M.H.; Vestena, A.S.; Cezarotto, C.S.; da Cruz, R.C.; Maurer, L.H.; Ferreira, L.M.; Emanuelli, T.; Cruz, L. Influence of harvest season and cultivar on the variation of phenolic compounds composition and antioxidant properties in Vaccinium ashei leaves. Molecules 2017, 22, 1603. [CrossRef] [PubMed]

73. Chandra, K.; Salman, A.S.; Mohd, A.; Sweety, R.; Ali, K.N. Protection against FCA induced oxidative stress induced DNA damage as a model of arthritis and in vitro anti-arthritic potential of Costus speciosus rhizome extract. Int. J. Pharmacogn. Phytochem. Res. 2015, 7, 383-389.

74. Muneer, S.; Park, Y.G.; Kim, S.; Jeong, B.R. Foliar or subirrigation silicon supply mitigates high temperature stress in strawberry by maintaining photosynthetic and stress-responsive proteins. J. Plant Growth Regul. 2017, 36, 836-845. [CrossRef]

75. Nahar, K.; Hasanuzzaman, M.; Alam, M.M.; Fujita, M. Exogenous spermidine alleviates low temperature injury in mung bean (Vigna radiata L.) seedlings by modulating ascorbate-glutathione and glyoxalase pathway. Int. J. Mol. Sci. 2015, 16, 30117-30132. [CrossRef] [PubMed]

76. Wu, X.; Yao, X.; Chen, J.; Zhu, Z.; Zhang, H.; Zha, D. Brassinosteroids protect photosynthesis and antioxidant system of eggplant seedlings from high-temperature stress. Acta Physiol. Plant. 2014, 36, 251-261. [CrossRef]

77. Amari, K.; Diaz-Vivancos, P.; Pallas, V.; Sanchez-Pina, M.A.; Hernandez, J.A. Oxidative stress induction by Prunus necrotic ringspot virus infection in apricot seeds. Physiol. Plant 2007, 131, 302-310. [CrossRef] [PubMed]

78. Kang, N.J.; Kang, Y.I.; Kang, K.H.; Jeong, B.R. Induction of thermotolerance and activation of antioxidant enzymes in $\mathrm{H}_{2} \mathrm{O}_{2}$ pre-applied leaves of cucumber and tomato seedlings. J. Jpn. Soc. Hortic. Sci. 2009, 78, 320-329. [CrossRef]

79. Zhu, T.; Deng, X.; Zhou, X.; Zhu, L.; Zou, L.; Li, P.; Zhang, D.; Lin, H. Ethylene and hydrogen peroxide are involved in brassinosteroid-induced salt tolerance in tomato. Sci. Rep. 2016, 6, 35392. [CrossRef] [PubMed]

80. Frugoli, J.A.; Zhong, H.H.; Nuccio, M.L.; McCourt, P.; McPeek, M.A.; Thomas, T.L.; McClung, C.R. Catalase is encoded by a multigene family in Arabidopsis thaliana (L.) Heynh. Plant Physiol. 1996, 112, 327-336. [CrossRef] [PubMed]

81. Mhamdi, A.; Queval, G.; Chaouch, S.; Vanderauwera, S.; Van Breusegem, F.; Noctor, G. Catalase function in plants: A focus on Arabidopsis mutants as stress-mimic models. J. Exp. Bot. 2010, 61, 4197-4220. [CrossRef] [PubMed]

82. Jaiswal, N.; Singh, M.; Dubey, R.S.; Venkataramanappa, V.; Datta, D. Phytochemicals and antioxidative enzymes defence mechanism on occurrence of yellow vein mosaic disease of pumpkin (Cucurbita moschata). Biotech 2013, 3, 287-295. [CrossRef] [PubMed]

83. Ahn, T.; Paliyath, G.; Murr, D.P. Antioxidant enzyme activities in apple varieties and resistance to superficial scald development. Food Res. Int. 2007, 40, 1012-1019. [CrossRef]

(C) 2018 by the authors. Licensee MDPI, Basel, Switzerland. This article is an open access article distributed under the terms and conditions of the Creative Commons Attribution (CC BY) license (http://creativecommons.org/licenses/by/4.0/). 